\title{
The History of Acta Biotheoretica and the Nature of Theoretical Biology
}

\author{
Thomas A. C. Reydon, Piet Dullemeijer \\ and Lia Hemerik ${ }^{1}$
}

\begin{abstract}
In this introductory chapter, the three most recent editors of Acta Biotheoretica briefly discuss the history, aims and nature of the journal in the context of the unique character of theoretical biology in The Netherlands. We stress that the broad conception of theoretical biology from which the journal has started almost 70 years ago has been maintained throughout all of its issues to the present day.
\end{abstract}

\subsection{INTRODUCTION}

Theoretical biology has existed as long as researchers have been interested in investigating the living world, although for most of the time it has not existed as an independent scientific discipline. In its earliest forms, theoretical biology can be understood as a general investigation into the nature of life and its development on Earth. In later stages, theoretical investigations became divided over several disciplines that study entities and phenomena on different levels of organization, from molecular biology to ecology.

Acta Biotheoretica, published for the first time in 1935, is one of the oldest international journals publishing in theoretical biology. Since its foundation, the journal has been devoted to the development and promotion of this field of investigation. As is illustrated in the following sections, the journal has continuously operated from a broad understanding on the nature of theoretical biology and has reflected the particular character of theoretical biology as it existed and still exists in The Netherlands. In this understanding, theoretical biology is seen as encompassing the entire spectrum of theoretical investigation of the living world, ranging from philosophy of biology to

${ }^{1}$ Piet Dullemeijer has been the Managing Editor of Acta Biotheoretica in the periods 1966 - 1969 and 1987 - 1998. Lia Hemerik has been the Managing Editor of the journal in the period 1999 - 2001. Since 2002 Thomas Reydon is the journal's present Managing Editor.

1

T.A.C. Reydon and L. Hemerik.,(eds.), Current Themes in Theoretical Biology,

$1-8$.

(C) 2005 Springer. Printed in the Netherlands. 
mathematical biology. Consequently, the process of biological theory formation in the journal is allowed to range from purely verbal argumentation to the mathematical analysis of biological theory. This diverse nature of the journal's scope is also reflected in the articles published in the present book.

In 2002, the $50^{\text {th }}$ volume of Acta Biotheoretica was published. Two of the editors, together with the publisher, felt that this jubilee should not pass unmarked and that an appropriate way to celebrate it would be to issue a book on the current state of theoretical biology in The Netherlands. The result of their co-operation together with the effort of the authors of the following ten chapters is now lying in front of you.

In this introductory chapter we briefly describe the history and scope of the journal Acta Biotheoretica in connection with the history of theoretical biology in The Netherlands. ${ }^{2}$ We aim to provide an insight into the nature of theoretical biology as it is reflected in the articles published in Acta Biotheoretica and in the present book, and as it has been understood by the journal's editors from the beginning of the journal to the present day. In Section 2, we focus on the journal's early history; in Section 3, we discuss in more detail the perspective on theoretical biology that is taken in the journal.

\subsection{THE JOURNAL'S ORIGIN AND EARLY YEARS}

Acta Biotheoretica has its origins in the 1930s when the number of researchers working in theoretical biology was showing a strong increase. Due to this increase, in combination with the problematic situation regarding the mailing system and the travelling difficulties at the time, maintaining personal contacts among theoretical biologists became a complicated matter. This was the case not only within the field of theoretical biology itself but also with the rest of biological science and with areas outside biology. In 1934 three academic friends decided to issue a journal as they were aware of the increase in the number of researchers in the area of theoretical biology and the obstacles for good communication. These three professional friends were C. J. van der Klaauw (a zoologist at Leiden University), J. A. J. Barge (a medical anatomist at Leiden University) and A. Meyer (a biologist at the University of Hamburg). With this journal these scientists wanted to establish an open forum that would exist over an extended period of time and that, among other things, would enable students and scholars to always return to the study of questions and problems in theoretical biology.

To achieve their goal of issuing a journal the three friends approached many researchers spanning almost the entire academic field of biology. They received a very strong positive response, among other things because they

${ }^{2}$ However, we are no historians and we must consequently leave a more thorough discussion of this matter to specialists. 
proposed to publish articles in the three modern European languages: French, English and German. Their idea was that every publication in the journal should be written in one of these three languages and be accompanied by summaries in the two other languages (Van der Klaauw et al., 1935: 3). ${ }^{3}$ Almost fifty researchers of a high standard responded in a positive way and agreed to support the three friends with respect to recommending new contributions and refereeing and editing submitted manuscripts. So, the three founders became the Board of the journal, and seven other scientists, each from a different country, were asked to form the Editorial Board. The others would constitute a main advisory team.

The new journal was called Acta Biotheoretica and started off with a support of the Jan van der Hoeven Foundation. ${ }^{4}$ It was " $(. .$.$) intended to be an$ international biological journal for the promotion of theoretical biology, being exclusively devoted to investigations on biological theories, particularly also the special mathematics and logic of biology." (Acta Biotheoretica 1 (1935): first printed page, no page number). In the years following the successful start of their journal, the editors supplemented Acta Biotheoretica with three additional series of publications. In 1936 Folia Biotheoretica was started, “(...) a series of introductory studies regarding theoretical biology. (...) Each number treats a certain subject and appears in connection with a symposium held at the University of Leyden." (Acta Biotheoretica 11 (1953-1956): inside front cover). In addition, to help students and scholars in gaining an overview of the available literature in their field, the editors collected references to typically theoretical papers and published these for subscribers in the Bibliographia Biotheoretica. This latter edition first appeared in 1938 and was discontinued in 1971, but lists of new titles in theoretical biology continued to appear in Acta Biotheoretica itself (Jeuken, 1971:1). This practice was discontinued when literature became available in Current Contents which itself later has been replaced by classified on-line literature search facilities covering almost all the literature in (theoretical) biology. Lastly, in 1941 the Bibliotheca Biotheoretica was established, “(...) a series of monographs on certain subjects of theoretical biology (...) [not aimed] at giving reviews in the

\footnotetext{
${ }^{3}$ From Volume 33 (1984) onward, the journal's official policy has become that papers should be written in English (Instructions for authors, Acta Biotheoretica 33 (1984): 63-66). Nevertheless, in later volumes papers in French have occasionally entered the journal's pages, for instance in special issues from the annual meeting of the Société Francophone de Biologie Théorique.

${ }^{4} \mathrm{Jan}$ van der Hoeven was Professor of Zoology at Leiden University from 1826 to 1868. The Jan van der Hoeven Foundation for Theoretical Biology (the full Dutch name of which is 'Prof. Dr. Jan van der Hoeven Stichting voor Theoretische Biologie van Dier en Mensch, verbonden aan de Universiteit te Leiden') was established in 1935 by C.J. van der Klaauw on the basis of a financial donation from the heirs of Jan van der Hoeven (Dullemeijer, 1976: 57) and exists to the present day.
} 
manner of a pure compilation, but bearing the personal stamp of the author and having a scientific, objective and critical character." (Acta Biotheoretica 11 (1953-1956): inside front cover). At present, Acta Biotheoretica is the only one of these four series that still continues to be published on a regular basis. (See also Dullemeijer, 1976: 57-59.)

The researchers who began to publish in Acta Biotheoretica attempted to bring to the surface the specific character and value of biological investigation. In the view of the majority of these investigators biology could not be reduced to physics, chemistry or mathematics, even though many of them began to use these other scientific disciplines to support their own work. The journal aimed at achieving and maintaining a high quality by publishing on a wide variety of topics. From the first issues onward, the topics that were addressed in the articles published in the journal spanned the entire spectrum of theoretical biology as it was understood by the founding editors (see the next section), ranging from philosophy of biology (for example, there were two papers on the question whether biology could be considered an autonomous science; Sapper, 1935 and 1936) to the mathematical foundations of biological science (e.g. Volterra, 1937). Because it was felt that the specific character and value of biological investigation required the input from scientific disciplines outside biology (at the time, biologists frequently acquired training in fields outside biology), the task of the journal was adapted to include the publication of articles from other disciplines that could help biologists in their work.

Although the start of Acta Biotheoretica was very successful, unfortunately the main efforts to build bridges between various areas of scientific investigation began just before the outbreak of the Second World War. The journal barely survived the war because of reinforced language barriers and the particular situation of the founding editors: Van der Klaauw was imprisoned by the Germans; Meyer was physically unable to travel and, if he could, he was not allowed; Barge was in danger and was already advanced in years. Although young co-workers tried to consolidate the journal, the communication system was almost broken down fully. Because of these bad circumstances the journal was in need of a completely new editorial system. In the meantime, in different countries researchers in theoretical biology were becoming organised differently and were going their own way, among other things because they were working in different disciplines between which there was not much contact.

After the war a new start had to be made. Although the original intention had been to publish one volume of the journal annually (see Acta Biotheoretica 1 (1935): first printed page, no page number), most of the volumes that were published from 1939 onward covered two to four years per volume (Volumes 5 to 13). After 1960 the publication frequency increased, but it was not until the late 1960s that Acta Biotheoretica was again published annually. Moreover, not all of the previously established connections could be 
repaired immediately and certainly not to the original extent. Due to the severed connections, in the years following the war the journal's editors were unable to achieve the journal's aim “(...) to bring into the sphere of international thought theories and views which at present are too much restricted to certain schools and certain countries." (Acta Biotheoretica 1 (1935): first printed page, no page number), hoping to "(...) put an end to the terrible fragmentation of biotheoretical thought." (Van der Klaauw et al., 1935: 2; translation TR). In stark contrast, the first issues of Acta Biotheoretica that were published after the war reflected the existing fragmentation of biological thought by containing mostly papers stemming from particular schools of theoretical research along with symposia reports of specialised disciplines or parts thereof. But as the situation improved a return to the original aims of the journal could be seen.

\subsection{DUTCH THEORETICAL BIOLOGY AND THE SCOPE OF ACTA BIOTHEORETICA}

In 1938, Van der Klaauw observed that theoretical biology “ (...) has not yet developed into a universally acknowledged department of biology, a fact which gives rise to a good deal of confusion in the application of the term (...)" and expressed the view that theoretical biology should be understood "(...) on as broad a basis as possible, so that the subject may later be able to develop itself freely along its own lines." (Van der Klaauw, 1938: vii). Fifty years later, worldwide theoretical biology had become a mature field of investigation, with its Dutch branch occupying a special position in the international scholarly landscape. As the philosopher Michael Ruse acknowledged in an overview of the state of affairs at the time in philosophy of biology:

"Holland has a small subdiscipline which seems virtually unique to that country. So-called theoretical biology runs the gamut from hardline mathematical modelling to serious study of the philosophical foundations of biology. To date, the subject's practitioners have perhaps been more successful at the mathematical end of the spectrum (...). Now, however, (...) a new generation of philosophically trained biologists is producing work on ethics, ecology, theory structure, and more (...)" (Ruse, 1988: 86).

Today, theoretical biology in The Netherlands still covers this entire spectrum.

While adopting the aim of the Jan van der Hoeven Foundation to develop "(...) a theoretical biology within, and strictly in the service of the science of practical biology" (Van der Klaauw, 1938: viii), Acta Biotheoretica's founding editors did not see theoretical biology as subordinate to the gathering of empirical data but as a field of work that was of value in itself: 
"Facts are regarded as parts of knowledge having eternal truth and validity, while theory is regarded rather as a necessary evil, a means by which facts may be deduced. (...) However, it is not true that theory is a necessary evil. It is only to secure the joy of knowledge that it [i.e. theory] gives us, that we search for the facts that can verify it." (Van der Klaauw et al., 1935: 1-2). ${ }^{5}$

Consequently, in their view theoretical biology should not only encompass the foundations on which practical biology could rest, but also the development of general theories that accounted for the phenomena studied in biological practice. This stance is reflected in the conception of the character of theoretical biology that the journal's founding editors adopted:

"By 'Theoretical Biology' is meant, in the first place theories and views of a general character regarding the biological sciences, in the second place the mathematical foundations of these sciences (...), in the third place the philosophical and logical foundations of the biological sciences (...)" (Acta Biotheoretica 11 (1953-1956): inside front cover). ${ }^{6}$

While this broad view of the field was retained throughout the journal's development to the present day, there were minor changes as new areas of investigation were opened up. Some of these new areas were included into the journal's scope, whereas others were not. When biochemistry became a promising new area of investigation, for instance, researchers in this field never used Acta Biotheoetica for publication of their theoretical results. Similarly, physiological genetics and developmental biology did not find their way to the journal's pages. Bioinformatics, however, was a field that did explicitly enter into the journal's scope. As the editor, M. Jeuken, asserted in an editorial in Volume 25 of the journal:

"Originally theoretical biology was only philosophy of biology.

About 1940 biomathematics came into the field. (...) Bioinformatics

is a new part of theoretical biology (...)." (Jeuken, 1976: i; cf.

Instructions for authors, Acta Biotheoretica 30 (1981)).

Similarly, the journal's scope was broadened to include studies into the foundations of biomedical science (excluding, however, biomedical ethics). One important new field of investigation that may in the near future explicitly enter the scope of the journal is systems biology, a field in which experimental

\footnotetext{
${ }^{5}$ Van der Klaauw and co-authors wrote their 'Foreword by the editors' partly in English, partly in German and partly in French. The first sentence of this quotation is from the English part of the foreword, the sentences after ' $(. .$.$) ' are from the German$ part (translation by TR).

${ }^{6}$ This conception of theoretical biology was adopted from the constitution of the Jan van der Hoeven Foundation. See also Van der Klaauw et al. (1935: 3) and Van der Klaauw (1938: vii-viii).
} 
biologists, biomathematicians and bioinformaticians have joined forces to understand how organisms work at various levels of organization (for recent overviews, see Kitano, 2001, 2002). In this field of investigation much co-operative work is currently being undertaken to enhance our understanding of living cells by means of modelling working cells in silica (Kitano, 2002; Nurse, 2003). (This, notably, notwithstanding the fact that until recently molecular biologists were not much interested in mathematical models of the cell.)

At present, the journal is conceived primarily as an international journal publishing on the mathematical and philosophical foundations of biological and biomedical science, as its subtitle since 2002 conveys (see Reydon, 2002: i). With respect to the philosophical end of the spectrum, the situation has changed considerably in the past decades. In 1976, Acta Biotheoretica's editor observed that "As regards philosophy of biology, this journal is practically the only one existing in this special area of thinking (...)" (Jeuken, 1976: i). By now, there exist several high-quality journals that publish specifically on philosophy of biology, such as Biology and Philosophy and Studies in the History and Philosophy of Biological and Biomedical Sciences. Whereas these journals focus more on philosophy of science, Acta Biotheoretica aims to present philosophical investigation as an integral part of the whole spectrum of theoretical science.

\subsection{CONCLUSION}

The papers collected in the present book are intended to reflect the diverse nature of theoretical biology as it is understood from the perspective of Acta Biotheoretica. Although due to severe cutbacks in research funding, philosophy of biology in The Netherlands is at present in far from a good shape, we still believe that a mature theoretical biology should essentially encompass research into both the mathematical and philosophical foundations of biological science. Moreover, Acta Biotheoretica should in our opinion continue to publish in both fields of work, as well as on topics that lie in between these two.

We hope that the present book may serve well to mark the publication of the journal's $50^{\text {th }}$ volume in 2002 , as well as the journal's $70^{\text {th }}$ birthday in 2005.

\section{REFERENCES}

Dullemeijer, P. (1976). Van Zoötomie tot Zoölogie: Een Historische Schets van de Leidse Algemene Dierkunde. Universitaire Pers Leiden, Leiden. Jeuken, M. (1971). Note of the editor. Acta Biotheoretica 20: 1. 
Jeuken, M. (1976). Note of the editor. Acta Biotheoretica 25: i.

Kitano, H. (Ed.) (2001). Foundations of Systems Biology. MIT Press, Cambridge, Mass.

Kitano, H. (2002). Computational systems biology. Nature 420: 206-210.

Nurse, P. (2003). Systems biology: understanding cells. Nature 424: 883.

Reydon, T. A. C. (2002). Editorial: Looking back, looking ahead. Acta Biotheoretica 50: i-ii.

Ruse, M. (1988). Philosophy of Biology Today. State University of New York Press, Albany, N.Y.

Sapper, K. (1935). Die Biologie als autonome Wissenschaft I. Acta Biotheoretica 1: 41-46.

Sapper, K. (1936). Die Biologie als autonome Wissenschaft II. Acta Biotheoretica 2: 12-18.

Van der Klaauw, C. J. (1938). Introduction. In: Van der Klaauw, C. J., J. A. J. Barge and A. Meyer (Eds). Bibliographia Biotheoretica 1925-1929. E. J. Brill, Leiden, pp. vii-xi.

Van der Klaauw, C. J., J. A. J. Barge and A. Meyer (1935). Foreword by the editors. Acta Biotheoretica 1: 1-4.

Volterra, V. (1937). Principes de biologie mathématique. Acta Biotheoretica 3: 1-36.

Thomas A. C. Reydon

Philosophy of the Life Sciences Group, Institute of Biology, Leiden University

Piet Dullemeijer

Mariahoevelaan 3, 2343 JA Oegstgeest, The Netherlands

Lia Hemerik

Biometris, Department of Mathematical and Statistical Methods,

Wageningen University 